

- With a time-specific point of determination and limited duration,

- Directed toward focal aspects of product acquisition and/or consumption.

Without doubt, customer satisfaction is one of the most widely studied and embraces constructs in marketing (Peterson and William, 1992, 61). Despite increasing customer satisfaction level should increase costs, the main target of the business known as "profit" increases simultaneously. It is always desirable to achieve superiority in both productivity and customer satisfaction (Anderson, Fornell, and Rust 1997, 129). High extensive documentation exist for the stylyez fact of a positive relationship between profitability and market share. To enrich market share, customer satisfaction is the most valuable technique (Bulding and Staelin, 1990, 1160; Huang, 2010, 20).

Municipalities as one of the public instutions are elected with votes of the people and use these revenues fort he peoples interest. Thus, customer satisfaction meaning people's satisfaction is always of crucial importance for municipalities. The better the quality of the services provided are, the better the customer satisfaction is. In fact, satisfaction of the citizens, the customers, could be considered as fulfillment of their needs. . Moreover, the public administration paradigm begun in 1980's has developed a management approach focused on citizens (Duman and Yüksel, 2008; 44). Satisfaction is the case that; the expectation before the act of buyingand the experience after the act of buying are satisfactory (Yaşa, 2012; 79).

\section{Concept of Municipality}

Municipalities are the instutions closest to the public. Because the duty of municipalities directly affects the daily lives of the people. Thus it is important that municipal services are appreciated by the people. Municipalities produce and sell goods and services, but does not seek profit. Municipalities are public legal entities. Improving socio-cultural and technological conditions have increased people's expectations from municipalities. Duty of the municipalities is to provide services to the people equally taking prenventive measures, to fulfill the services according to the people's expectations and supervise the services (Yücel et al., 2012; 152).

Municipal employees consist of three main groups as permanent staff, contract workers and sub-contract workers. The employees' incomes and the rights they gain vary according to the departments they work and their staff status. It has been observed that the earnings and rights of permanent employees increase according to their work hours and education. Municipality is a local government authority and there are two types of municipalities: metropolitan municipality and district municipality.

Local administrations, municipalities, are the fundamental factor of democtatic life in the province, district or town. In Turkey, central administration have given municipalities wide authorities to make industrial or commercial enterprises to adresss their needs with legal regulations towards municipalities in various eras (Titiz, 2010; 9).

Duties of municipalities are specified with the Law. The content of the Law: "Municipality, as long as it is of local and common quality;performs and has performed the services such as urban infrastructure; geographical and urban infirmation systems; environment and environmental health; sanitation and solid waste; municipal police, fire fighters, immediate aid, rescue and ambulance; local traffic; funeral services and cemeteries; planting, parks and green-fields; domiciles; culture and arts, tourism, youth and sports; social services and aid, weddings, economy and promotion of commerce; town planning,water and sewerage services, transportation. Metropolitan mucipalities and municipalities with a population more that 50.00 opens protection houses for women and children" (www.transanatolie.com).

Municipalities are instutions responsible for performing and controlling many services specified with laws such as quality infrastructure, environment, education, health, culture and social aid. The demand for municipal services increases in our day in which urban population keeps rising with births and immigrations. 
The fact that citizens' expectations are rising is making municipalities an instution capable of producing any kind of solution (Erdoğan 2010; 471).

As stated in other researches and articles, munipalities as local administrations, are responsible for making the regulations towards public needs. It is essential in this aspect to examine processes in municipalities which have a crutial role in public's level of peace inreasing. Those who perform municipal functions are municipal employees. Municipal employees ought to do their jobs at their best for a good service. The employees who are satisfected with their jobs would be obliged to respect the service codes in municipalities exactly not to lose their jobs. Municipalities as local administrations are getting more important by day. It can be said that the localisation inclinations happening around the world has a major part in this. People are increasingly inclined to car efor the citiez they live in. Thus, responsibilities of municipalities are crutial (Henden, 2007; 94). Municipalities produce services which effect daily life directly. Thus, munipalities are under a huge burden to satisfy the public, their widest customer portfolio. Municipalities are localinstutions which are commisioned to provide the public needs. Municipalities each are servise producers as organisations, and people are the customer. Municipal employees are of high importance in providing customer satisfaction. Plannings, foundedlocal systems, services that run the daily lifeand inspection of those are done by municipal employees. Taking into consideration that job satisfaction of municipal employees has an effect on the service they provide, it is thought that for keeping public welfare high, employees satisfactions ought to be high as well. The importance of municipal services shows us that the public coul as well be affected from negative cases.

\section{METHODOLOGY}

\section{Establishing Research Scales}

By the means of this research, it has been observed that there had been many researches conducted on job satisfaction and customer satisfaction as a result of wide scope researches in management literature. Among the scales examined, those which have been selected would give the best result in our country has been added in this study. The job satisfaction scale we used in our research, originally "Job Satisfaction Survey" was established by Paul E. Spector in 1994. In this scale which aims to assess the employees' behaviour are 36 questions. The 36 questions have 9 sub-dimentions. These factors; pay, promotion, supervision, fringe benefits, contingent rewards, operatin conditions, coworkers, nature of work and communication.

These scales which originally use 5 point sysem are converted into 7 point Likert scale. Asssessment options for every question in the surveys are the following: (1) Totally disagree, (2) disagree, (3) partially disagree, (4) neither agree nor disagree, (5) partially agree, (6) agree, (7) totally agree. Reverse scales in the job satifaction survey were primarily converted into normal due to the rule.

\section{Collecting Samples and Data}

Kadıköy and Maltepe Municipalities have been chosen because of their high numbers of employees in this study which focuses on İstanbul munipal employees and customers (public). The relevant survey had been conducted in every building and operating places of the relevant munipalities with permissions of the mayors in order to construct an effective universe of samples which adresses to every employee.

The method of survey has been used through the research as means of collecting data. The survey had been sent to Kadıköy and Maltepe Municipalities along with the official letter and after getting the permits in written the employees had been began to be surveyed face to face in distrubution and coollection of the surveys. It has been detected that the employees were dainty in filling in a survey on job satisfaction. An environment of trust had been tried to established saying that the survey's purpose were all scientific, it was going to be used for a master's thesis collecting the data with statistical programs, and it was going to be filled in anonymously. Enforcing the environment of trust, getting rid of the problems to occur when the 
surveys were to be filled face to face.The survey of citizen (customer) satisfaction have been filled in by citizens and shopkeepers who live in the verge of Kadıköy and Maltepemuncipalities.

A total of 155 individuals have participated in the survey from Kadıköy Municipality employees, being 91 females and 64 males. Of these employees 12 individuals are factorary school graduates, 30 high school graduates, 22 collage graduates ( 2 years), 72 collage graduates (4 years), 17 with master's degree and 2 with doctorates. 96 of them are permanent employees and 59 of them are contract workers. Income state average is 2357,10 Turkish Liras, and standar deviation is 806,93 Turkish Liras. The employees' Professional experience average is 10,83 years and Standard deviation is 8,683 years.A total of 142 citizens have participated in the survey from Kadıköy Municipality verge, being 59 females and 83 males. 14 of these citizens are factorary school graduates, 47 are high school graduates, 19 collage graduates ( 2 years), 54 collage graduates (4 years), 8 have their master's degree. Income state average is 2643,66 Turkish Liras, and standart deviation is 3180,80 Turkish Liras. The citizens' residence duration average is 14,89 years and standard deviation is 11,124 years.A total of 137 individuals have participated in the survey from Maltepe Municipality employees, being 65 females and 72 males. Of these employees 12 individuals are factorary school graduates, 47 high school graduates, 17collage graduates ( 2 years), 52collage graduates (4 years), 8 with master's degree and 1 with doctorates. 84 of them are permanent employees and 53 of them are contract workers. Income state average is 2302,55 Turkish Liras, and standar deviation is 714,923 Turkish Liras. The employees' Professional experience average is 9,28 years and Standard deviation is 8,045 years.

At last, a total of 138 citizens have participated in the survey from Maltepe Municipality verge, being 54 females and 84 males. 15 of these citizens are Factorary School graduates, 51 are high school graduates, 22 collage graduates ( 2 years), 42 collage graduates (4 years), 6 have their master's degree and 2 have their doctorates. Income state average is 2499,64 Turkish Liras, and standar deviation is 1932,374 Turkish Liras. The citizens' residence duration average is 14,49 years and Standard deviation is 11,999 years.

Even though the scales used in the research were scientifically efficient and had been used in other studies, they were re-checked and went through reliability analysis. The factors in the scales have been included in the factors they depend on and reliability analysed. During this process first the Croncbachalfa $(\alpha)$ values were considered. It has been checked that if the results were under 0,500 after looking into the correlation parameters (correctedinter - itemcorelation) among the factors.. When alfa values are checked it is seen that every factor are reasonably higher then the acceptence value of 0.700 without subtracting any factors.

The 9 factors in job satisfaction scale have been compared with customer satisfaction. It has been claimed that each and every factor has a seperate effect directly and positively and 18 hypothesises has been created being 9 in Maltepe Municipality and 9 in Kadiköy Municipality. One hypothesis have been created as comparison hypothesis. This hypothesis suggests that the analysis results of Kadıköy and Maltepe would be close. It is 22. Research model and reliability, correlation, regression analysis resulşts are stated below. Job satisfaction and customer satisfaction surveys have been detected to be reliable following reliability surveys. All the values were reasonably higher then 0,700 which the threshold value is. 


\section{Model for the Effects of Job Satisfaction Factors to Citizen Satisfaction}

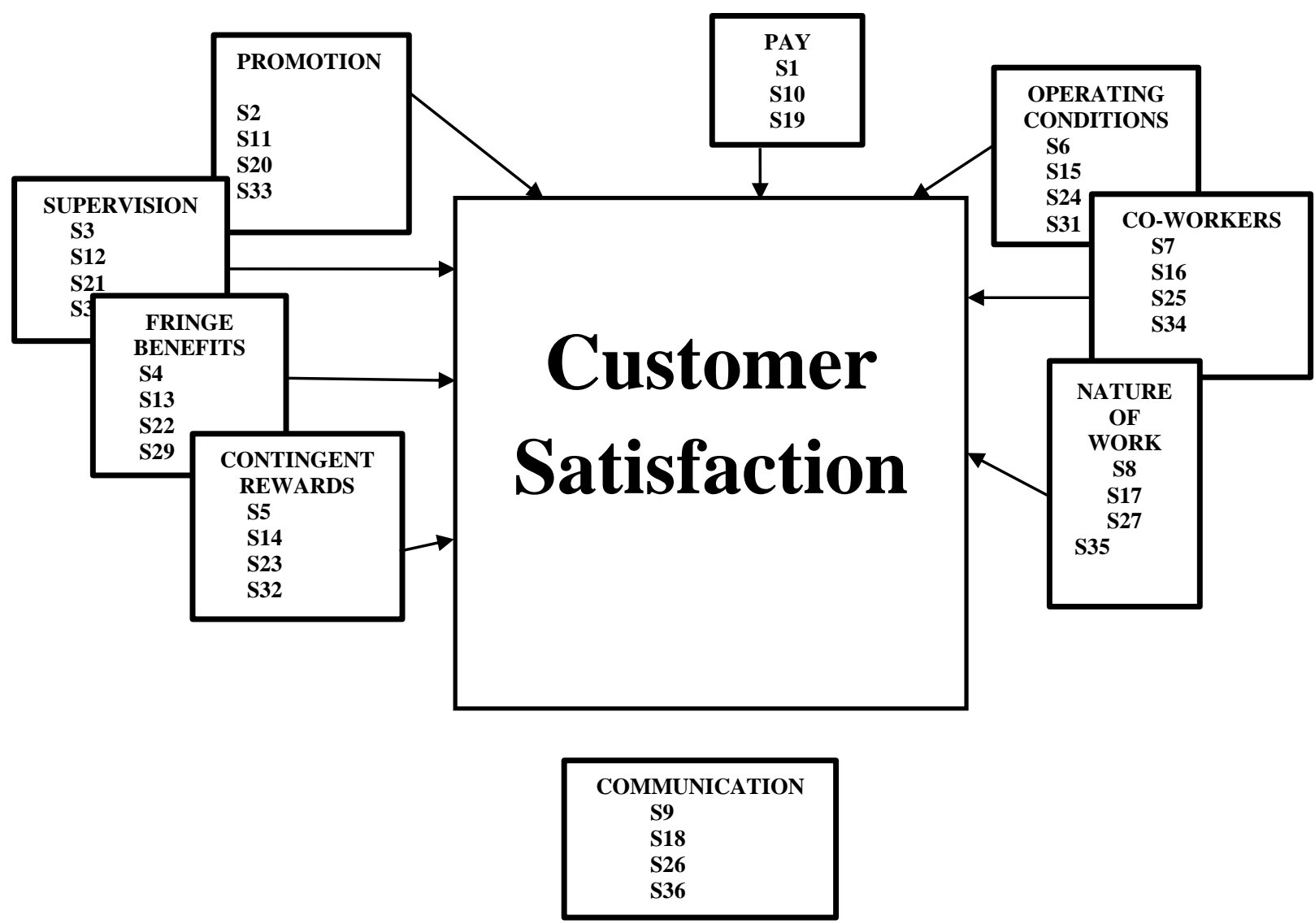

\section{Reliability Analysis}

While Cronbach Alpha value of the citizen (customer) satisfaction survey conducted in Maltepe Municipality showed up to be 916, the one in Kadıköy Municipality had its Croach Alpha value 925. 138 individuals in Maltepe Municipality borders and 142 in Kadıköy Municipality borders were applied this survey.

- Reliability results of the job satisfaction survey applied in Maltepe Municipality are as following:

\begin{tabular}{lccccccccccc} 
& $\mathbf{1}$ & $\mathbf{2}$ & $\mathbf{3}$ & $\mathbf{4}$ & $\mathbf{5}$ & $\mathbf{6}$ & $\mathbf{7}$ & $\mathbf{8}$ & $\mathbf{9}$ \\
\hline Cronbach's - Alpha: &, 921 &, 862 &, 923 &, 912 &, 916 &, 765 &, 891 &, 889 &, 883 & & \\
KMO: &, 830 &, 827 &, 845 &, 839 &, 858 &, 728 &, 803 &, 814 &, 831 &
\end{tabular}

- Reliability results of the job satisfaction survey applied in Kadıköy Municipality are as following:

\begin{tabular}{lrrrrrrrrrr} 
& 1 & 2 & 3 & 4 & 56 & 7 & 8 & 9 \\
\hline Cronbach's - Alpha: &, 811 &, 857 &, 897 &, 856 &, 892 &, 783 &, 815 &, 819 &, 818 \\
KMO: &, 765 &, 793 &, 844 &, 798 &, 835 &, 728 &, 743 &, 787 &, 786
\end{tabular}




\section{Factor Analysis}

The structoral effectiveness of the scale being used in our research have been tested through SPSS program using factor analysis methods and the scale was checked for being multi-factoral or not. The model will be checked with correlation and regression analysisis after the factors used for testing the model are confirmed reliable and effective. The results of factoranalysisis of job satisfaction scale are presented in the table below.

Factor Analysis of Job Satisfaction Scale (Maltepe)

\begin{tabular}{cccccccccc} 
& 1 & 2 & 3 & 4 & 5 & 6 & 7 & 8 & 9 \\
\hline KMO: &, 830 &, 827 &, 845 &, 839 &, 858 &, 728 &, 803 &, 814 &, 831
\end{tabular}

Factor Analysis of Job Satisfaction Scale (Kadıköy)

\begin{tabular}{cccccccccc} 
& 1 & 2 & 3 & 4 & 5 & 6 & 7 & 8 & 9 \\
\hline KMO: &, 765 &, 793 &, 844 &, 798 &, 835 &, 728 &, 743 &, 787 &, 786
\end{tabular}

Job satisfaction scale is divided into 9 sub-factors (pay, promotion, supercision, nature of work, coworkers, communication, operating conditions, contingent rewards, fringe benefits) as expected. The factor loads attained to the questions belonging to the sub-factors are stated above. It has been detected that KaiserMeyer-Olkin (KMO) value is 0,700 and above in this case the structoral effectiveness of the scale means no problem.

In our experimental research, after testing the scales applied to Kadıköy and Maltepe municipal employees and the citizens of these two municipalities with reliability analysis, factors about performance and job satisfaction were created taking the averages of every factor attained to each factor.Justbefore going on with regression analysis to be examined between dependent and independent factors, correlation technique which examines the one on one relationships between factors were adapted to the scale.

\section{Correlation Analysis}

Table 1: Maltepe Municipality Correlation Analysis Table

\begin{tabular}{|c|c|c|c|c|c|c|c|c|c|c|c|c|}
\hline & Average. & SD & 1 & 2 & 3 & 4 & 5 & 6 & 7 & 8 & 9 & 10 \\
\hline Pay & 3,9799 & 1,74528 & 1 & & & & & & & & & \\
\hline Promotion & 3,4635 & 1,52206 &, $334 * *$ & 1 & & & & & & & & \\
\hline Supervision & 4,7336 & 1,48157 & ,162 & ,063 & 1 & & & & & & & \\
\hline Fringe Benefits & 4,4051 & 1,60827 &, $679 * *$ & ,294** &, $222 * *$ & 1 & & & & & & \\
\hline $\begin{array}{l}\text { Contingent } \\
\text { Rewards }\end{array}$ & 3,7281 & 1,62655 &, $368 * *$ & ,379** & ,376** & ,216* & 1 & & & & & \\
\hline $\begin{array}{l}\text { Operating } \\
\text { Conditions }\end{array}$ & 3,9380 & 1,13143 & ,004 & ,134 & ,012 & $-0,41$ & ,075 & 1 & & & & \\
\hline Coworkers & 4,9489 & 1,28950 &, 053 & ,068 &, $380 * *$ & ,147 &, $269 * *$ & , 099 & 1 & & & \\
\hline Nature of Work & 5,2263 & 1,36119 & ,439** &, $293 * *$ & ,334** &, $506 * *$ &, $360 * *$ & $\overline{-}$, &, $344 * *$ & 1 & & \\
\hline Communication & 4,3595 & 1,44757 &, 164 &, $259 * *$ &, $480 * *$ & ,145 &, $378 * *$ & ,120 &, $494 * *$ &, $348 * *$ & 1 & \\
\hline $\begin{array}{l}\text { Customer } \\
\text { Satisfaction }\end{array}$ & 3,7696 & 1,19020 & ,091 & ,030 & ,066 &,- 038 &, $189 *$ & ,074 &,- 043 & ,018 & ,117 & 1 \\
\hline
\end{tabular}


Table 2: Kadıköy Municipality Correlation Analysis Table

\begin{tabular}{|c|c|c|c|c|c|c|c|c|c|c|c|c|}
\hline & Average. & SD & 1 & 2 & 3 & 4 & 5 & 6 & 7 & 8 & 9 & 10 \\
\hline Pay & 3,6500 & 1,43292 & 1 & & & & & & & & & \\
\hline Promotion & 3,1710 & 1,47235 &, $369 * *$ & 1 & & & & & & & & \\
\hline Supervision & 4,9032 & 1,44020 &, $224 * *$ & 139 & 1 & & & & & & & \\
\hline Fringe Benefits & 3,7871 & 1,58134 &, $657 * *$ &, $402 * *$ &, $269 * *$ & 1 & & & & & & \\
\hline $\begin{array}{c}\text { Contingent } \\
\text { Rewards }\end{array}$ & 3,6548 & 1,56521 &, $327 * *$ &, $362 * *$ &, $479 * *$ &, $373 * *$ & 1 & & & & & \\
\hline $\begin{array}{l}\text { Operating } \\
\text { Conditions }\end{array}$ & 3,8613 & 1,13036 & ,179* & ,306*** &, $276 * *$ &, $188 *$ &, $487 * *$ & 1 & & & & \\
\hline Coworkers & 4,9452 & 1,22052 &, $313 * *$ & ,186* &, $413 * *$ & ,134 &, 350 *** & ,170* & 1 & & & \\
\hline Nature of Work & 4,9081 & 1,29247 &, $508 * *$ &, $240 * *$ &, $464 * *$ & ,346** &, 350 *** & ,064 & ,291** & 1 & & \\
\hline Communication & 4,4371 & 1,27844 &, $373 * *$ &, 356 *** &, $457 * *$ &, $339 * *$ &, $516 * *$ &, $121 * *$ &, 410 *** & ,493** & 1 & \\
\hline $\begin{array}{l}\text { Customer } \\
\text { Satisfaction }\end{array}$ & 3,8643 & 0,99104 & ,109 & ,013 & ,100 & ,191* & 095 & ,100 & ,147 &,- 008 & 0,56 & 1 \\
\hline & & & $\begin{array}{l}* * \mathbf{C o} \\
* \mathbf{C o}\end{array}$ & $\begin{array}{l}\text { ation } \\
\text { ation }\end{array}$ & $\begin{array}{l}l \text { is goo } \\
l \text { is goo }\end{array}$ & $\begin{array}{l}0.01 \\
0.05\end{array}$ & $\begin{array}{l}\text { Tailed) } \\
\text { Tailed) }\end{array}$ & & & & & \\
\hline
\end{tabular}

\section{Regression Analysis}

The regression analysis conducted in the research shows relationship between independent variables and dependent variables. This means the positive or negative effects on dependent variables caused by the changes in independent variables is examined by the means of this analysis.

\section{Maltepe Municipality Regression Analysis Results}

\section{Table 3: Contingent Rewards Variable Regression Analysis}

\begin{tabular}{|c|c|c|c|}
\hline \multirow{4}{*}{ Contingent Rewards } & $\boldsymbol{\beta}$ & $\mathbf{t}$ & $\mathbf{p}$ \\
\hline & 0,189 & 2,237 & $\mathbf{0 . 0 2 7}$ \\
\hline & \multicolumn{3}{|c|}{ Dependent Variable : Customer Satisfaction } \\
\hline & $\mathbf{R}^{2}=\mathbf{0 , 0 3 6}$ & $F=5,004$ & $P=0,027$ \\
\hline
\end{tabular}

contingent rewards used on employees has increased the customer satisfaction on citizens in Maltepe by $R^{2}$ value, 0.036 , in other words directly $\% 3.6$. According to the regression analysis results, contingent rewads has a direct and positive effect on customer satifaction considering the level of significance and beta level $(0,189)$.

This case could be interpreted as the significance of contingent rewards for increasing the quality of services of Maltepe Municipal employees besides from their pays and social facilities. It is considered that extra pay depending on performance could increase the service quality more that employee pay sor social rights.

\section{Kadıköy Municipality Regression Analysis Results}

\begin{tabular}{|c|c|c|c|}
\hline & $\boldsymbol{\beta}$ & $\mathbf{t}$ & $\mathbf{p}$ \\
\cline { 2 - 4 } & $\mathbf{0 , 1 9 1}$ & $\mathbf{2 , 3 0 1}$ & $\mathbf{0 . 0 2 3}$ \\
\hline
\end{tabular}




\begin{tabular}{|l|llr|}
\hline Fringe Benefits & \multicolumn{3}{|c|}{ Dependent Variable : Customer Satisfaction } \\
& $R^{2}=0,36$ & $F=5,293$ & $P=0,023$ \\
\hline
\end{tabular}

\section{sVariable Regression Analysis}

It has been seen that the fringe benefits used on employees has increased the customer satisfaction on citizens in Kadıköy by $R^{2}$ value, 0.36 , in other words directly \%36. According to the regression analysis results, fringe benefits have a direct and positive effect on customer satifaction considering the level of significance and beta level $(0,191)$.

The variable of fringe benefits directly effected the customer satisfaction in Kadıöy Municipal area. Though the results differ compared to Maltepe Municipality, these results support each other. Both factors points the importance of extra incomes acquirable for performance excluded from pay and social rights.

According to the results of the research it has been detected that job satisfaction of the employees in Maltepe and Kadıköy municipalities has no direct effect on customer satisfaction, but exceptionally contingent rewards in Maltepe Municipality and fringe benefits in Kadıköy Municipality directly and positively effect customer satisfaction.Regression analysis results for other factors examined in the research are shown below. In the comparisons made, it has been seen that 2 factors has direct effects on customer satisfaction.

\section{CONCLUSION}

Nine factors observed in the research have shown that only one factor has direct effect on customer satisfaction in each municipality. These elemets have been detected to be fringe benefits factor in Kadıköy Municipality, while is is contingent rewards in Maltepe Municipality. When the factors are examined it draws attention that they are both factors that provides extra incomes both spiritually and materially besides the salary. It is considered that the fact that the employees are salary earners could be related to this situation. It can be estimated that the employees who does not get extras for their performance besides from their salary could only work as much as needed and because they have no motives to do more generally they can not provide more performance for a better service.

Encouraging contingent rewards should be used to reward the employees who succeed in their performances and productivities with more than their salary for incrasing the service quality, customer satisfaction, endless renowation works and their loyality to the organisation. It can be said in this context that, when extra provisions which the municipal employees can acquire for their performance are established, the service quality and consequently the customer satisfaction would increase. The employees' point of view to the contingent rewards is also important. The contingent rewards must be of a level that would draw their attention.

Seven factors used in the research but have not had any direct effect on customer satisfaction on both municipalities which are such as pay, promotion, supervision, operating conditions, coworkers, nature of the work, communication are being considered to be the factors that effects the employees' job satisfactions. Because of the variety of the employees, the answers have varied as well. It is considered that acquired answers do not support each other because the employees were of different pays, different positions, different operating conditions, and with coworkers and supervisors. Despite that, it is generally thought that the customer satisfaction would increase as a result of better service quality, resulting from employees being happy with their jobs. Although not direcly effective, these factors which effects job satisfaction, obviously consequently effects customer satisfaction.But surveying the employees for detecting the direct effect is advisable. It is thought that local studies could bring better results. More accurate results could be acquired after examining every department in municipality's functional structures seperately. The reason for that is, as told before, employees being working in different conditions in every department. 
As a general view, the fact that employees work for certain provisions (material and spiritual incomes), and these provisions being encouraging increases the customer satisfaction. It has been assessed that the pay or rights of the employees do not direcly contribute to customer satisfaction, but the employees who knows that they could get more provisions then usual for their performances could provide a better service, thus increasing the customer satisfaction.

As we see it has been seen that providing employees with high salaries or more social rights, beter operating environments does not directly contribute to customer satisfaction. In fact this is not suprising. Getting what his reward from a work is every human's right as well as one of the greatest pleasures. Then rights and pays which salaried employees think they could not get even though they did over time sometimes may lead them to the thought that as long as they work just as enough they can get the pay and rights they could ever get any ways. This case may result in employees not doing more that enough. Contingent rewards and extra pay would animate their instinct to success. Those who embrace their work could be more creative. Extra pays to employees should not be considered as an unnecessary expense by the supervisors. The thought of "they get paid to do this anyways" could put the chill between the employee and the job. The extra pays and the rights given should be considered as the most valuable investigations. 


\section{REFERENCES}

ANDERSON, Eugene W., FORNELL, Claes and RUST, Roland T. (1997), 'Customer Satisfaction, Productivity, and Profitability: Differences between Goods and Services’, Marketing Science, Vol.16 No.2, pp. 129-145.

BOULDING, William, and STAELIN, Richard, (1990). "Environment, Market Share and Market Power”, Management Science 36, No.10, 1160-1177.

AYTÜRK, Nihat (2001). "Örgütlerde İş Basitleştirme ve İş Verimini Yükseltme Teknikleri". Amme İdaresi Dergisi. 34 (1), 79-112. Article.

BAYSAL, Ayşe Can (1993). ÇalışmaYaşamındaİnsan, Avcıol Basın Yayın, Fakülte Publish Number:225, İstanbul.

DAVIS, Keith (1988). "İşletmelerde İnsan Davranışı", Translate: Kemal Tosun İ. Ü.İşletme Fakültesi Press No:199, İstanbul.

DUMAN, Teoman and YÜKSEL, Fatih (2008), Çağdaş Yerel Yönetimler Dergisi

EKER, Gülden (2006). Örgütsel Adalet Algısı Boyutları Ve İş Doyumu Üzerindeki Etkileri, Dokuz Eylül University, Master Thesis.

ERDOĞAN, Hasan (2010). "Belediye Yatırımlarının Finansmanında Yap- İşlet -DevretAlternatifi: Antalya Sarısu Mesire Alanı Örneği". Süleyman Demirel Üniversitesi İktisadi ve İdari Bilimler Fakültesi Dergisi Cilt15, Say1:3

EREN, Erol (2001). Örgütsel Davranış ve Yönetim Psikolojisi. Extended Second Edition, Beta Basım Yayım Dağıtım A.Ş., İstanbul.

HUANG, Xiaoke, (2000), The Economics Of Recent U.S. Mergers And Acquisitions, Colorado, Thesis.

JAHANSHAH, A.A, GASTHI, M.A.H., MIRDAMADI, S.A, NAWASER, K. KHAKSAR, S.M.S. (2011)

"Study the Effects of Customer Service and Product Quality on Customer Satisfaction and Loyalty", International Journal of Humanities and Social Science Vol. 1 No. 7

JOAN L. Giese and JOSEPH A. Cote (2000), "Defining Consumer Satisfaction," Academy of

Marketing Science Review [Online] 00 (01) 00 (01) Available:

http://www.amsreview.org/articles/giese01-2000.pdf

MIHIÇOĞLU, Cemal (1979). Yönetimde İnsan İlişkileri Ders Notları. Ankara University, Siyasal Bilgiler Fakültesi, Ankara.

PETERSON, Robert A. and WILLIAM R. Wilson. (1992). "Measuring Customer Satisfaction: Fact and Artifact." Journal of the Academy of Marketing Science 20 (Winter): 61-71.

SABUNCUOĞLU, Zeyyat and VERGILİEL TÜZ, Melek (2008).ÖrgütselPsikoloji 4.Baskı Bursa

TELMAN, Nursel and ÜNSAL, Pınar (2004) Çalışan Memnuniyeti, Epsilon Yayınevi, İstanbul TíTIZZ, İsmet.(2010) "Belediyeler ve Bölgesel Kalkınma" OkutanYayıncılık, Yerel Siyaset Dergisi. Article

TRANSANATOLIE (www.transanatolie.com/ic/Doc/bldgyvi.pdf). İnternet site Access date: (21.04.2013).

TOK, Türkay Nuri, (2004). İlk Öğretim Müfettişlerinin İş Doyumu ve Örgütsel Bağl1lıkları.Ankara Üniversitesi Eğitim Bilimleri Enstitüsü. Ankara, Doctorate Thesis

YAŞA, Eda, 2012. Çukurova Üniversitesi Sosyal Bilimler Enstitüsü. Sağllk Sektöründe Hizmet Kalitesi, Müşteri Memnuniyeti ve Bağll1ık İlişkisi, Doctorate Thesis 
YÜCEL, Nurcan, et. al (2012). '’Belediyelerde Hizmet Pazarlaması: Elazı̆̆ Belediyesi Örneği’. Niğde University, İ̈BF Dergisi Cilt:5, Sayı:2

ZEHİR, Cemal; ELÇi, Meral; SAVİ, Fatma Zehra (2003), ”Ethical Climate's Relationship to Job Satisfaction, Organizational Commitment And Turnover Intention" Ethics 2003 Business And Professional Ethics Conference, Hacitepe Üniversitesi, Ankara 2003. 